\title{
Organic and Inorganic Pigments from Commercial Inks Used in Eyebrows' Microblading: Approach for Assessing the Safety Use by Bacterial Reverse Mutation Assay
}

\author{
Célia Marisa Oliveira-Ramos'ㄹ, Edson Hideaki Yoshida ${ }^{2}$, Yoko Oshima-Franco², \\ Valquíria Miwa Hanai-Yoshida ${ }^{*}$ (1) \\ ${ }^{1}$ Graduate Program in Technological and Environmental Processes, University of Sorocaba, Sorocaba, Brazil \\ ${ }^{2}$ Graduate Program in Pharmaceutical Sciences, University of Sorocaba, Sorocaba, Brazil \\ Email: *valquiria.yoshida@prof.uniso.br
}

How to cite this paper: Oliveira-Ramos, C.M., Yoshida, E.H., Oshima-Franco, Y. and Hanai-Yoshida, V.M. (2021) Organic and Inorganic Pigments from Commercial Inks Used in Eyebrows' Microblading: Approach for Assessing the Safety Use by Bacterial Reverse Mutation Assay. Journal of Cosmetics, Dermatological Sciences and Applications, 11, 330-341. https://doi.org/10.4236/icdsa.2021.114027

Received: November 6, 2021

Accepted: December 7, 2021

Published: December 10, 2021

Copyright $\odot 2021$ by author(s) and Scientific Research Publishing Inc. This work is licensed under the Creative Commons Attribution International License (CC BY 4.0).

http://creativecommons.org/licenses/by/4.0/

\section{(c) (i) Open Access}

\begin{abstract}
Background and Objective: The aesthetic products' safety should not be neglected to the detriment of the market. This study aimed to evaluate the mutagenic potential of commercial inks. It was formulated with organic (P1) and inorganic (P2) pigments for eyebrows microblading using a validated method by regulatory agencies, the Salmonella/microsome assay, to assure the safety of use. Methods: The assay was carried out in three steps: preliminary toxicity, medium without $(-S 9)$, and presence $(+S 9)$ of metabolic activation. The strains, auxotrophic to histidine (His-) TA97a, TA98, TA100, and TA102, were exposed to both types of inks, in triplicate, compared to negative and positive controls. Data were statistically analyzed, and values with mutagenic index $\geq 2.0$ were indicative of mutagenicity. Results: The inks with organic (P1) and inorganic (P2) pigments were not toxic to TA98 and TA100 $S$. typhimurium tester strains, even at concentrations applied in humans. Both inks were not mutagenic either in the absence or presence of metabolic activation in the tested concentrations, including that applied in humans. The assay showed that P1 and P2 were not direct (-S9) or indirect (+S9) mutagens as commercially formulated. Conclusions: These results indicate that applying these inks on organisms with microsomal enzymes, including humans, is safe since no compound in the inks became more toxic to induce the bacterial reverse mutation.
\end{abstract}

\section{Keywords}

Ames Test, Cosmetic Tattooing, Microblading 


\section{Introduction}

The aesthetic and its relationship to business ethics was an issue deeply discussed by Ladkin [1] and reinforced by the incontestable fact that all human beings value physical appearance. More than a simple act of vanity, the aesthetic accompanies an essential requirement for health and psychosocial well-being, as well as beautifying, repairing, treating, protecting, and harmonizing appearance [2]. It can reintegrate and recover the individual's self-esteem through corrections and aesthetic repairs in the psychosocial context.

With the technological advances and the increased growth in the aesthetics area, new cosmetic products and beauty procedures arise [3], necessary to regulate the products often used as off-label. Brazil Ministry of Health, according to RDC 55/2008, regulates the registration with requirements, changes, and adaptations that allow the safety and quality of the products for the procedures of these services [4].

Among numerous aesthetic recourses, the tattoo is included, which sometimes was interpreted as a symbol of marginalization [5], and modernly is interpreted as a form of expression and corporal art used by celebrities and ordinary citizens within the society [6]. Eyebrows' microblading or cosmetic tattooing can positively affect the appearance of the human being, providing besides the beautification of the eyebrows, the repair and reconstruction of them by partial or total losses by psychosomatic, metabolic, traumatic problems, among others. Products that present formulas regularized for commercialization guarantee the safety, quality, durability, and fixation in the procedures' results.

Professionals of the aesthetic area usually inject pigments' suspension into the skin (the target being the dermis) using needles, which are actuated by apparatus known as "dermograph". A fraction of the injected colorant remains in the dermis as particles, and their light absorption within a specific spectral range results in the color of the microblading. Another fraction of the injected colorant is removed from the skin via the lymphatic or blood vessel systems. As a result, microblading colorants can be found in the lymph nodes located next to the received inks with pigments or dyes [5] [7] [8] [9].

A classification of the inks with pigments or dyes can be made concerning the chemical structure, subdivided into organic and inorganic [10] [11]. For an organic compound to exhibit color is necessary that its chemical structure (the main groups are of the azo and polycyclic types) allows electronic resonances, being able to absorb electromagnetic radiation in the visible spectral region. Inorganic pigments or dyes have a pervasive application and are often combined with organic dyes. These exhibit high chemical stability and high dyeing power [11].

Vasold and co-workers [12] conducted an extensive analysis of many tattoo compounds and found that the most current commercially available tattoo compounds are organic pigments. Furthermore, in color tattoos, mainly, the red pigments cause many allergic reactions. Therefore, the black colors are very used, 
the latter consisting of carbon black, which has been listed by the International Agency of Research on Cancer (IARC) as possibly carcinogenic to humans (group 2B) [13], or by-products of the production of soot. Another common reason for complications after microblading is the dye found in the microblading pigment because some people can be allergic to this dye which causes an inflammatory reaction in the skin [14].

It reported that some tattoo pigments remain on the skin because the particles are insoluble and too large to be transported [5]. Assuming that the organic and inorganic pigments, due to their physical and chemical properties, are metabolized in different ways by the human organism in the deep epidermis, it is assumed that the process of phagocytosis results in variable durability of pigmentation in the skin for different types of pigments, in addition to varying levels of toxicity.

The Ames test [15] could be used to evaluate mutagenicity in inks with organic and inorganic pigments samples. This test assesses whether the substances pose a potential risk to human health and genetic damage leading to mutagenicity. Salmonella typhimurium strains derived from the LT2 (Heat-labile Toxins, LT) parental, auxotrophic for histidine (His) were used in the Ames test. Modified Salmonella does not synthesize histidine (it has different mutations in the histidine operon). They are constructed to detect table-type displacement-type mutations or substitution of base pairs in DNA. These lineages cannot grow in a minimal culture medium without histidine unless mutations occur that restore their ability to synthesize. Mutated bacteria do not produce histidine; if they mutate upon exposure to a test chemical, it reverts to its wild state producing histidine [16].

In this way, aiming to assure safety, this study's objective was to evaluate the mutagenicity of commercial organic and inorganic inks using bacterial reverse mutation assay.

\section{Materials and Methods}

\subsection{Commercial Inks Samples}

Commercial inks were used as samples formulated with organic pigments $(\mathrm{Rb}$ kollors $^{\circledR}, 1.004518$ ) and inorganic pigments (Mag Gold ${ }^{\circledR}, 1$. 003166EI). Label information from $\mathrm{Rb}$ kollors ${ }^{\circledR}$ for the ink with organics pigments (P1) shows the following composition: (CI $11741\left(\mathrm{C}_{18} \mathrm{H}_{18} \mathrm{~N}_{4} \mathrm{O}_{6}\right)$, CI $12475\left(\mathrm{C}_{8} \mathrm{H}_{8} \mathrm{O}_{3}\right)$, CI 21110 $\left(\mathrm{Cl}_{4} \mathrm{H}_{21} \mathrm{NO}_{3}\right)$, CI $51319\left(\mathrm{C}_{34} \mathrm{H}_{22} \mathrm{C}_{12} \mathrm{~N}_{4} \mathrm{O}_{2}\right)$, CI $73915\left(\mathrm{C}_{22} \mathrm{H}_{16} \mathrm{~N}_{2} \mathrm{O}_{2}\right)$, CI 74160 $\left(\mathrm{C}_{32} \mathrm{H}_{16} \mathrm{CuN}_{8}\right)$, CI $74260\left(\mathrm{C}_{32} \mathrm{C}_{116} \mathrm{CuN}_{8}\right)$, CI $77266(\mathrm{C})$, and CI $\left.77891\left(\mathrm{TiO}_{2}\right)\right)$, water, 1,2-propanediol, 1,2,3-propanetriol, and nonionic surfactant. Moreover, label information from Mag Gold ${ }^{\circledR}$ manufacturer for the ink with inorganics pigments (P2) shows that it may contain CI $77891\left(\mathrm{TiO}_{2}\right), \mathrm{CI} 77493(\mathrm{ZnO}), \mathrm{CI}$ $15850\left(\mathrm{C}_{18} \mathrm{H}_{12} \mathrm{~N}_{2} \mathrm{Na}_{2} \mathrm{O}_{6} \mathrm{~S}\right)$, CI $77289\left(\mathrm{Cr}_{2} \mathrm{H}_{4} \mathrm{O}_{5}\right)$, CI $77491\left(\mathrm{Fe}_{2} \mathrm{O}_{3}\right)$, CI 77499 $\left(\mathrm{Fe}_{3} \mathrm{O}_{4}\right)$, and $\left.\mathrm{CI} 77007\left(\mathrm{Al}_{6} \mathrm{Na}_{6} \mathrm{O}_{24} \mathrm{~S}_{8} \mathrm{Si}_{6}\right)\right)$, water, isopropyl alcohol, and distilled glycerin pigments. 


\subsection{Salmonella typhimurium Tester Strains}

The $S$. typhimurium tester strains TA97a, TA98, TA100, and TA102 were kindly provided by B.N. Ames; Berkeley, CA, USA). Strains are stored in cryogenic 2.0 $\mathrm{mL}$ vials (For each $0.9 \mathrm{~mL}$ of culture was added $0.1 \mathrm{~mL}$ of dimethyl sulfoxide (DMSO, Sigma-Aldrich ${ }^{\circledR}$ ), a cryo-protectant) and kept in the ultra-low temperature vertical freezer $\left(\operatorname{Revco}{ }^{\circledR}\right)$ at the Lapetox-Laboratory of Toxicological Research-University of Sorocaba, at $-80^{\circ} \mathrm{C}$ so that all of them remain unchanged their genetic characteristics.

\subsection{Metabolic Activation System (S9 Mixture)}

The S9 was purchased from Moltox ${ }^{\circledR}$ (11'01L rat liver LS-9/Aroclor 1254-induced male Sprague-Dawley rat liver). The mixture contains pooled enzymes and metabolic cofactor, nicotinamide adenine dinucleotide phosphate (NADPH), salts, phosphate buffer, and sterile distilled water [17].

\subsection{Positive and Negative Controls}

All mutagens (positive controls) were purchased from Sigma-Aldrich ${ }^{\circledR}$. Those used in the absence of the S9 mixture (-S9) were 4-nitro-O-phenylenediamine $\left(10.0 \mu \mathrm{g} \cdot\right.$ plate $\left.^{-1}\right)$ for TA98 and TA97a, sodium azide $\left(1.25 \mu \mathrm{g} \cdot\right.$ plate $\left.^{-1}\right)$ for TA100, and mitomycin $\left(0.5 \mu \mathrm{g} \cdot\right.$ plate $\left.^{-1}\right)$ for TA102. In the presence of S9 mixture (+S9) were 2 -anthramine $\left(1.25 \mu \mathrm{g} \cdot\right.$ plate $\left.^{-1}\right)$ for TA98, TA97a, and TA100 strains, and 2-aminofluorene $\left(1.25 \mu \mathrm{g} \cdot\right.$ plate $\left.^{-1}\right)$ for TA102. Dimethyl sulfoxide (DMSO, Sigma-Aldrich $\left.{ }^{\circledR}\right)$ served as the negative (solvent) control $\left(50 \mu \mathrm{L} \cdot\right.$ plate $\left.^{-1}\right)$.

\subsection{Preliminary Toxicity Test}

Toxicity tests were performed in triplicate for both P1 and P2 inks exposed to TA98 and TA100 strains, without metabolic activation (-S9), and using $1 \mathrm{~mL}$ each, and subsequent decreasing solution of $0.8,0.6,0.4,0.2$, and $0.1 \mathrm{~mL}$, which were completed with $0.2,0.4,0.6,0.8$ and $0.9 \mathrm{~mL}$ of DMSO, respectively.

Briefly, the samples' toxicity is evidenced by the complete absence of growth, reduction in the number of His+ revertants, or a background in the minimal glucose agar test plates compared to the spontaneous negative control and control plates. A decrease in the growth of colonies with reverse mutation under spontaneous control may indicate partial toxicity, in which case the surviving bacteria still form microcolonies. The absence of colony growth and background growth indicates a high degree of toxicity that impairs bacterial growth and the formation of background growth [18] [19].

This step is essential since the studied compound cannot be toxic to bacterial, and the used concentrations should allow a minimum growth of $\sim 0.6$-times the concurrent control [20].

\subsection{Salmonella/Microsome Assay (Ames Test)}

The Ames test was performed using the preincubation method [17]. An incubation step before plating characterizes the preincubation method [20]. In the 
presence and absence of the metabolizing system, the cultures of bacteria and the mixture containing the test sample are preincubated for $20-30 \mathrm{~min}$ at $37^{\circ} \mathrm{C}$ (Figure 1).

\subsection{Data Interpretation}

The mutagenic index (MI) was calculated for each concentration tested. The average number of revertants per plate with the test compound was divided by the average number with the negative (solvent) control. A sample was considered mutagenic when a dose-response relationship was detected, and a 2-fold increase in the number of mutants, $\mathrm{MI} \geq 2$, was observed with at least one concentration [21].

\subsection{Statistical Analysis}

The results were analyzed using the Salanal statistical software package (U.S. Environmental Protection Agency, Monitoring Systems Laboratory, Las Vegas, NV, version 1.0, from Research Triangle Institute, RTP, North Carolina, USA), adopting the Bernstein and coworkers [22] model. The data (revertants plate ${ }^{-1}$ ) were assessed by analysis of variance (ANOVA), followed by linear regression. A $\mathrm{p}<0.05$ was taken to indicate statistical significance.

\section{Results}

\subsection{Preliminary Toxicity Test}

The preliminary toxicity test (Table 1 ) showed that P1 and P2 inks, when exposed to TA98 and TA100 strains, do not cause toxicity to the strains (no statistical difference in revertant colonies compared to negative control was found), even without any dilution.

TA98 and TA100 were selected for this test since they are susceptible strains for detecting carcinogens [15]. Based on these preliminary toxicity tests performed with pigment P1 and P2 by diluting both inks' suspensions, the same concentrations were selected for the Ames test.

Table 1. Toxicity test of P1 and P2 in strains TA98 and TA100.

\begin{tabular}{ccccc}
\hline \multicolumn{3}{c}{ Dilutions of inks in DMSO (v/v) } & \multicolumn{2}{c}{ Results } \\
\hline \multicolumn{2}{c}{ Pigments $(\mathrm{v} ; \mathrm{mL})$} & DMSO $(\mathrm{v} / \mathrm{mL})$ & TA98 & TA100 \\
\hline $\mathrm{P} 1$ & $\mathrm{P} 2$ & & & non-toxic \\
\hline $0.1 \mathrm{~mL}$ & $0.1 \mathrm{~mL}$ & $0.9 \mathrm{~mL}$ & non-toxic & non-toxic \\
$0.2 \mathrm{~mL}$ & $0.2 \mathrm{~mL}$ & $0.8 \mathrm{~mL}$ & non-toxic & non-toxic \\
$0.4 \mathrm{~mL}$ & $0.4 \mathrm{~mL}$ & $0.6 \mathrm{~mL}$ & non-toxic & non-toxic \\
$0.6 \mathrm{~mL}$ & $0.6 \mathrm{~mL}$ & $0.4 \mathrm{~mL}$ & non-toxic & non-toxic \\
$0.8 \mathrm{~mL}$ & $0.8 \mathrm{~mL}$ & $0.2 \mathrm{~mL}$ & non-toxic & non-toxic \\
$1.0 \mathrm{~mL}$ & $1.0 \mathrm{~mL}$ & $0.0 \mathrm{~mL}$ & non-toxic & nonn
\end{tabular}

Abbreviations: DMSO, Dimethyl sulfoxide; P1, organic pigment; P2, inorganic pigment. 


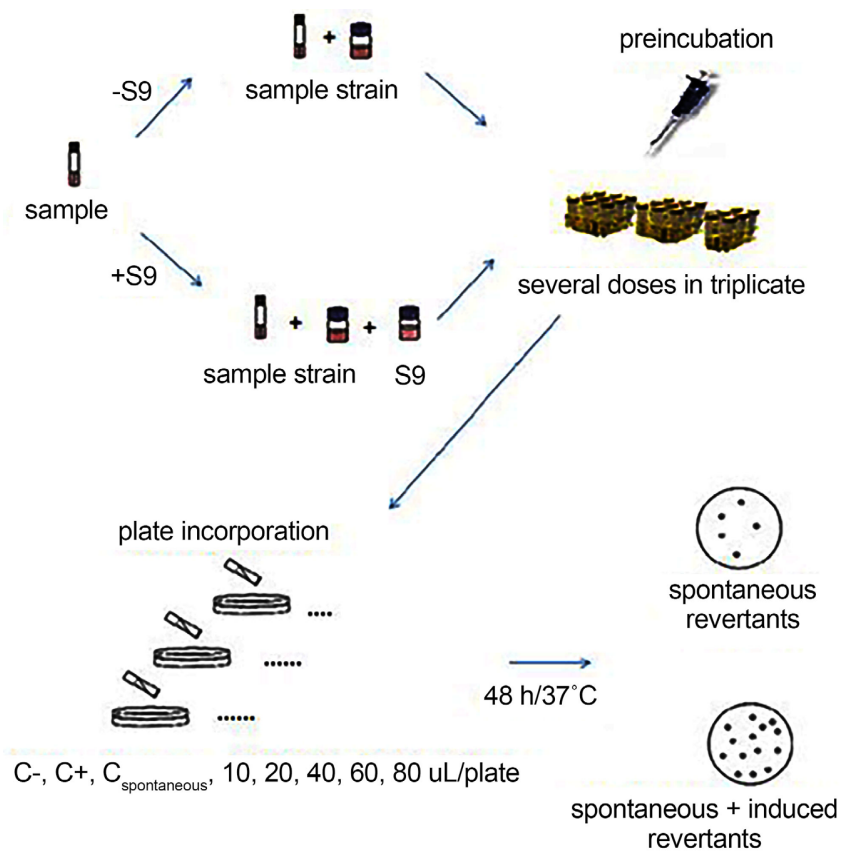

Figure 1. Scheme of the Ames test by the method of incorporation in plates with previous incubation.

\subsection{Ames Test Results}

The mutagenicity evaluation study using the Ames test (Salmonella/microsome) for inks with organic pigments (P1) and inorganic pigments (P2) are shown in Table 2 and Table 3. The controls were in recommended standards in all the tests, which gives the samples' obtained results reliability.

Notice that all studied concentrations of P1 did not cause bacterial reverse mutation (MI $<2.0)$, showing that P1 has no direct activity on tested strains $(-S 9)$ nor when exposed to metabolic activation $(+S 9)$, showing that P1 has no indirect activity on tested strains.

The results clearly show the absence of mutagenicity in all studied concentrations of P2, in a medium without metabolic activation (-S9) or with (+S9), denoting that this pigment has no direct nor indirect activity to reverse the genotype characteristics of the studied strains.

\section{Discussion}

The Ames test was performed in laboratories worldwide to evaluate a large variety of chemicals as the first step in assessing genotoxic risks, including even by our research group.

The ease and low cost of the Ames test make it invaluable for screening substances in our environment for possible carcinogenicity. This test also presents a guide to predict interactions between chemical compounds and DNA [23].

There are few studies about cosmetic products using Salmonella/microsome assay. One of them was made using henna (Lawsonia alba), and the authors conclude that henna is not mutagenic [24]. The scarce data in literature may be due 
to studies made in chemical isolated and not as the final product [25], or cosmetic industries may perform Ames tests as part of the genetic toxicity testing battery required by regulatory agencies to enable marketing of the products [26], with no interest in scientific divulgation. Even in developed continents, this issue is yet secondary, as seen at the European level, where there is no binding regulation governing the components used in tattoo inks [27].

In this study, we set out the concern of professionals from the aesthetic area who work injecting pigments' suspension into the skin (at dermis level), with no or little information about the safety of these pigments, besides the inherent risks for both patients and aesthetic workers resulting from the route of administration [28]. In addition, the off-label use of certain compounds opens an insecure "aesthetic window" for both professionals and clients. Here, we intended to minimize the uncertainty about organic and inorganic pigments used in eyebrows' microblading, using a bacterial reverse mutation assay, a validated and accepted test for regulatory agencies.

Table 2. Revertants plate $^{-1}$, standard deviation, and mutagenicity index (MI, in parentheses) for $S$. typhimurium strain TA98, TA100, TA102, and TA97a after the treatment with various doses of ink with pigment (P1: RB Kollors $\left.{ }^{\circledR}\right)$ suspension.

\begin{tabular}{|c|c|c|c|c|}
\hline \multirow{3}{*}{$\begin{array}{c}\text { Treatments } \\
\text { P1: RB Koloors } \\
\mu \mathrm{L} \cdot \text { plate }^{-1}\end{array}$} & \multicolumn{4}{|c|}{ Number of revertants $(\mathrm{M} \pm \mathrm{DP}) /$ plate and $\mathrm{MI}$} \\
\hline & \multicolumn{2}{|c|}{ TA98 } & \multicolumn{2}{|c|}{ TA100 } \\
\hline & $-S 9$ & + S9 & $-S 9$ & $+\mathrm{S} 9$ \\
\hline $0.0 \mathrm{a}$ & $23 \pm 1$ & $38 \pm 4$ & $137 \pm 5$ & $158 \pm 5$ \\
\hline 10.0 & $22 \pm 6(1.0)$ & $42 \pm 3(1.1)$ & $110 \pm 7(0.8)$ & $182 \pm 7^{\star}(1.2)$ \\
\hline 20.0 & $20 \pm 2(0.9)$ & $39 \pm 3(1.0)$ & $100 \pm 12(0.7)$ & $180 \pm 4^{\star *}(1.1)$ \\
\hline 40.0 & $21 \pm 2(0.9)$ & $33 \pm 2(0.9)$ & $100 \pm 10(1.0)$ & $178 \pm 3^{\star \star}(1.1)$ \\
\hline 60.0 & $18 \pm 2(0.8)$ & $35 \pm 3(0.9)$ & $102 \pm 8(0.7)$ & $161 \pm 3(1.0)$ \\
\hline 80.0 & $27 \pm 3(1.2)$ & $32 \pm 3(0.8)$ & $102 \pm 11(0.7)$ & $140 \pm 9(0.9)$ \\
\hline \multirow[t]{2}{*}{ Ctrol+ } & $756 \pm 133 b$ & $2076 \pm 61 \mathrm{e}$ & $1413 \pm 86 c$ & $1437 \pm 43 \mathrm{e}$ \\
\hline & \multicolumn{2}{|c|}{ TA102 } & \multicolumn{2}{|c|}{ TA97a } \\
\hline $0.0 \mathrm{a}$ & $263 \pm 18$ & $275 \pm 13$ & $138 \pm 5$ & $156 \pm 9$ \\
\hline 10.0 & $205 \pm 35(0.8)$ & $247 \pm 5(0.9)$ & $110 \pm 21(0.8)$ & $178 \pm 7(1.1)$ \\
\hline 20.0 & $174 \pm 7(0.7)$ & $246 \pm 2(0.9)$ & $100 \pm 3(0.7)$ & $166 \pm 6(1.1)$ \\
\hline 40.0 & $181 \pm 11(0.7)$ & $269 \pm 2(1.0)$ & $93 \pm 6(0.7)$ & $150 \pm 9(1.0)$ \\
\hline 60.0 & $177 \pm 4(0.7)$ & $229 \pm 3(0.8)$ & $98 \pm 3(0.7)$ & $135 \pm 5(0.9)$ \\
\hline 80.0 & $167 \pm 2(0.6)$ & $226 \pm 7(0.8)$ & $143 \pm 17(1.0)$ & $135 \pm 5(0.9)$ \\
\hline Ctrol+ & $1203 \pm 79 d$ & $1366 \pm 46 f$ & $854 \pm 118 b$ & $2405 \pm 88 \mathrm{e}$ \\
\hline
\end{tabular}

Notes: Ctrol-, Negative control: dimethylsulfoxide ${ }^{\mathrm{a}}\left(\mathrm{DMSO}-50 \mu \mathrm{L} \cdot\right.$ plate $^{-1}$ ); Ctrol+, Positive control - b4-nitro-o-phenylenediamine ${ }^{\mathrm{b}}$ (NOPD - $10.0 \mu \mathrm{g} \cdot \mathrm{plate}^{-1}$ - TA98, TA97a); sodium azide ${ }^{c}\left(1.25 \mathrm{mg} \cdot\right.$ plate $^{-1}-$ TA100); mitomycin $^{\mathrm{d}}\left(0.5 \mu \mathrm{g} \cdot\right.$ plate $^{-1}-\mathrm{TA}$ 102), in the absence of S9 and 2-anthram ${ }^{\mathrm{e}}\left(1.25 \mu \mathrm{g} \cdot\right.$ plate $^{-1}$ - TA 97a, TA98, TA100); f2-aminofluorene $\mathrm{f}^{\mathrm{f}}\left(10.0 \mu \mathrm{g} \cdot\right.$ plate $\left.^{-1}-\mathrm{TA102}\right)$ in the presence of S9. Abbreviations: $\mathrm{M} \pm$ $\mathrm{SD}$, mean and standard deviation; MI, mutagenicity index. ${ }^{*}, \mathrm{p}<0.05{ }^{* *}, \mathrm{p}<0.01$. 
Table 3. Revertants plate $^{-1}$, standard deviation, and mutagenicity index (MI, in parentheses) for $S$. typhimurium strain TA98, TA100, TA102, and TA97a after the treatment with various doses of ink with pigment (P2: Gold MagColor $\left.{ }^{\circledR}\right)$ suspension.

\begin{tabular}{|c|c|c|c|c|}
\hline \multirow{3}{*}{$\begin{array}{l}\text { Treatments } \\
\text { P2: Gold } \\
\text { MagColor } \\
\mu L \cdot \text { plate }^{-1}\end{array}$} & \multicolumn{4}{|c|}{ Number of revertants $(\mathrm{M} \pm \mathrm{DP}) /$ plate and $\mathrm{MI}$} \\
\hline & \multicolumn{2}{|c|}{ TA98 } & \multicolumn{2}{|c|}{ TA100 } \\
\hline & $-S 9$ & $+\mathrm{S} 9$ & $-S 9$ & + S9 \\
\hline $0.0 \mathrm{a}$ & $32 \pm 6$ & $26 \pm 2$ & $131 \pm 15$ & $142 \pm 4$ \\
\hline 10.0 & $27 \pm 5(0.8)$ & $23 \pm 5(0.9)$ & $148 \pm 49(1.1)$ & $137 \pm 5(1.0)$ \\
\hline 20.0 & $25 \pm 4(0.8)$ & $25 \pm 4(1.0)$ & $139 \pm 12(1.1)$ & $151 \pm 4(1.1)$ \\
\hline 40.0 & $23 \pm 7(0.7)$ & $26 \pm 7(1.0)$ & $128 \pm 37(1.0)$ & $143 \pm 5(1.0)$ \\
\hline 60.0 & $21 \pm 4(0.7)$ & $27 \pm 3(1.0)$ & $125 \pm 12(0.9)$ & $153 \pm 12(1.1)$ \\
\hline 80.0 & $25 \pm 2(0.8)$ & $23 \pm 5(0.9)$ & $112 \pm 16(0.9)$ & $150 \pm 7(1.1)$ \\
\hline \multirow[t]{2}{*}{ Ctrol+ } & $756 \pm 133 b$ & $2076 \pm 61 \mathrm{e}$ & $1413 \pm 86 c$ & $1437 \pm 43 \mathrm{e}$ \\
\hline & \multicolumn{2}{|c|}{ TA102 } & \multicolumn{2}{|c|}{ TA97a } \\
\hline $0.0 \mathrm{a}$ & $330 \pm 12$ & $345 \pm 13$ & $155 \pm 7$ & $144 \pm 6$ \\
\hline 10.0 & $320 \pm 17(1.0)$ & $308 \pm 17(0.9)$ & $136 \pm 10(0.9)$ & $145 \pm 4(1.0)$ \\
\hline 20.0 & $337 \pm 12(1.0)$ & $291 \pm 67(0.8)$ & $147 \pm 8(0.9)$ & $144 \pm 8(1.0)$ \\
\hline 40.0 & $348 \pm 12(1.1)$ & $308 \pm 25(1.0)$ & $135 \pm 17(0.9)$ & $139 \pm 4(1.0)$ \\
\hline 60.0 & $381 \pm 19^{\star}(1.2)$ & $329 \pm 47(1.1)$ & $144 \pm 12(0.9)$ & $143 \pm 10(1.0)$ \\
\hline 80.0 & $408 \pm 31^{\star}(1.2)$ & $310 \pm 23(1.0)$ & $148 \pm 6(1.0)$ & $137 \pm 8(1.0)$ \\
\hline Ctrol+ & $1203 \pm 79 d$ & $1366 \pm 46 f$ & $854 \pm 118 b$ & $2405 \pm 88 \mathrm{e}$ \\
\hline
\end{tabular}

Notes: Ctrol-, Negative control: dimethylsulfoxide ${ }^{\mathrm{a}}\left(\mathrm{DMSO}-50 \mu \mathrm{L} \cdot\right.$ plate $^{-1}$ ); Ctrol+, Positive control - b4-nitro-o-phenylenediamine ${ }^{\mathrm{b}}$ (NOPD - $10.0 \mu \mathrm{g} \cdot \mathrm{plate}^{-1}$ - TA98, TA97a); sodium azide ${ }^{c}\left(1.25 \mathrm{mg} \cdot\right.$ plate $^{-1}$ - TA100); mitomycin ${ }^{\mathrm{d}}\left(0.5 \mu \mathrm{g} \cdot \mathrm{plate}^{-1}\right.$ - TA102), in the absence of S9 and 2-anthram ${ }^{\mathrm{e}}\left(1.25 \mu \mathrm{g} \cdot\right.$ plate $^{-1}$ - TA 97a, TA98, TA100); f2-aminofluorene $\mathrm{f}^{\mathrm{f}}\left(10.0 \mu \mathrm{g} \cdot \mathrm{plate}^{-1}-\mathrm{TA102}\right)$ in the presence of S9. Abbreviations: $\mathrm{M} \pm$ $\mathrm{SD}$, mean and standard deviation; MI, mutagenicity index. ${ }^{*}, \mathrm{p}<0.05$.

Regarding safety for human use, the results obtained with the P1, without metabolic activation (-S9), showed no mutagenicity nor indication of mutagenicity for all tested strains. Furthermore, when P1 was subjected to the metabolizing system $(+S 9)$, the mutagenic indexes did not show values $\geq 2$ in all tested strains, showing that the organic pigment does not form intermediates by microsomal enzymes liver, which could increase its toxicity.

The P2, when submitted to the test of mutagenicity in the absence of metabolic activation (-S9), was also very safe, not causing reversion on the tested strains. Again, when P2 was submitted to the metabolic activation system (+S9) showed no value of $I M \geq 2.0$. The microsomal biotransformation did not produce toxic intermediate products, leading to changes in $S$. typhimurium strains.

The target mutations of Salmonella tester strains in this study exhibit the DNA (deoxyribonucleic acid) sequences where mutagens reverse them to wild type [29]. TA98 induces a frameshift mutation, affecting a nearby repetitive 
-C-G-C-G-C-G-C-G- sequence [30]. TA100 strain induces the substitution of leucine (GAG/CTC) by a proline (GGG/CCC) [31], causing base-pair substitution mutations. TA102 strain contains AT base pairs at the hisG428 mutant site, which mutation is carried on the multi-copy plasmid pAQ1 to amplify the number of target sites, which in turn confers tetracycline resistance, a convenient marker to detect the presence of the plasmid. In this strain, the uvrB gene was retained (differently from other Salmonella strains), making the bacterium DNA repair proficient and enhancing the ability of this strain to detect DNA cross-linking agents, like those caused by bleomycin and mitomycin $\mathrm{C}$ (used here as positive control) [32]. The hisG428 mutation is an ochre mutation (TAA) in the hisG gene, in which the reversion involves transitions and transversions events. TA97 induces frameshift mutation in a run of 6 cytosines (-C-C-C-C-C-C-), as seen by TA98 [33].

Our results clearly show that the $\mathrm{P} 1$ and $\mathrm{P} 2$ pigments could not induce changes to reverse $S$. typhimurium tester strains' genotype characteristics to wild type.

\section{Conclusion}

The authors conclude that as commercially formulated P1 and P2 were not direct (-S9) nor indirect $(+S 9)$ mutagens. These results show that these pigments' application on organisms with microsomal enzymes, including humans, is safe since no compound in the pigments became more toxic to induce the bacterial reverse mutation.

\section{Authors' Contributions}

Conceptualization, V.M.H.Y. and C.M.O.; methodology, V.M.H.Y. and Y.O.F.; validation, E.H.Y.; formal analysis, V.M.H.Y., and Y.O.F.; investigation, C.M.O., and E.H.Y.; resources, V.M.H.Y. and Y.O.F.; data curation, C.M.O., and E.H.Y.; writing original draft preparation C.M.O., V.M.H.Y. and Y.O.F.; writing review and editing, V.M.H.Y.; visualization, V.M.H.Y. and Y.O.F.; supervision, V.M.H.Y.; project administration, V.M.H.Y.; funding acquisition, V.M.H.Y., and Y.O.F. All authors have read and agreed to the published version of the manuscript.

\section{Funding and Acknowledgements}

This study was funded by Fundação de Amparo à Pesquisa do Estado de São Paulo-FAPESP, grant number 2015/01420-9. The authors would like to thank the University of Sorocaba for the scholarship grant, Mag Estética and RB Colors, to donate $\mathrm{P} 1$ and $\mathrm{P} 2$ samples, respectively.

\section{Conflicts of Interest}

The authors declare no conflicts of interest regarding the publication of this paper.

\section{References}

[1] Ladkin, D. (2018) “The Aesthetic” and Its Relationship to Business Ethics: Philo- 
sophical Underpinnings and Implications for Future Research. Journal of Business Ethics, 147, 35-51. https://doi.org/10.1007/s10551-015-2928-2

[2] Soaigher, K.A., Acencio, F.R. and Cortez, D.A.G. (2016) The Power of Vanity and Self-Care in Quality of Life "O poder da vaidade e do autocuidado na qualidade de vida”. Cinergis, 18, 69-72. https://doi.org/10.17058/cinergis.v18i1.8218

[3] Bilal, M., Mehmood, S. and Iqbal, H. (2020) The Beast of Beauty: Environmental and Health Concerns of Toxic Components in Cosmetics. Cosmetics, 7, Article No. 13. https://doi.org/10.3390/cosmetics7010013

[4] Brazil (2008) RDC n. 55 de 6 de Agosto de 2008. https://bvsms.saude.gov.br/bvs/saudelegis/anvisa/2008/res0055_06_08_2008.html

[5] Hauri, U. and Hohl, C. (2015) Photostability and Breakdown Products of Pigments Currently Used in Tattoo Inks. Current Problems in Dermatology, 48, 164-169. https://doi.org/10.1159/000369225

[6] Pérez, A.L. (2006) A identidade à flor da pele: Etnografia da prática da tatuagem na contemporaneidade. Mana, 12, 179-206. https://doi.org/10.1590/S0104-93132006000100007

[7] Soran, A., Kanbour-Shakir, A., Bas, O. and Bonaventura, M. (2014) A Tattoo Pigmented Node and Breast Cancer. Bratislava Medical Journal, 115, 311-312. https://doi.org/10.4149/BLL_2014_063

[8] Balasubramanian, I., Burke, J.P. and Condon, E. (2013) Painful, Pigmented Lymphadenopathy Secondary to Decorative Tattooing. The American Journal of Emergency Medicine, 31, 1001.e1-1001.e2. https://doi.org/10.1016/j.ajem.2013.02.011

[9] Klügl, I., Hiller, K.-A., Landthaler, M. and Bäumler, W. (2010) Incidence of Health Problems Associated with Tattooed Skin: A Nation-Wide Survey in German-Speaking Countries. Dermatology, 221, 43-50. https://doi.org/10.1159/000292627

[10] Herbst, W., Hunger, K., Wilker, G., Ohleier, H. and Winter, R. (2004) Review of Chemical Structures and Chemical Reactions. In: Herbst, W., Hunger, K., Wilker, G., Ohleier, H. and Winter, R. (Eds.) Industrial Organic Pigments: Production, Properties, Applications, Wiley-VCH Verlag GmbH \& Co. KGaA, Weinheim, 601-636. https://doi.org/10.1002/3527602429.app1

[11] Saron, C. and Felisberti, M.I. (2006) Influence of Colorants on the Degradation and Stabilization of Polymers "Ação de colorantes na degradação e estabilização de polímeros”. Química Nova, 29, 124-128.

https://doi.org/10.1590/S0100-40422006000100022

[12] Vasold, R., Engel, E., König, B., Landthaler, M. and Bäumler, W. (2008) Health Risks of Tattoo Colors. Analytical and Bioanalytical Chemistry, 391, 9-13. https://doi.org/10.1007/s00216-008-1978-Z

[13] Working Group on the Evaluation of Carcinogenic Risks to Humans (2006) Inorganic and Organic Lead Compounds. IARC Monographs on the Evaluation of Carcinogenic Risks to Humans, No. 87, International Agency for Research on Cancer, Lyon. https://www.ncbi.nlm.nih.gov/books/NBK321297/?report=classic

[14] de Cuyper, C., Lodewick, E., Schreiver, I., Hesse, B., Seim, C., Castillo-Michel, H., Laux, P. and Luch, A. (2017) Are Metals Involved in Tattoo-Related Hypersensitivity Reactions? A Case Report. Contact Dermatitis, 77, 397-405. https://doi.org/10.1111/cod.12862

[15] Ames, B.N., Mccann, J. and Yamasaki, E. (1975) Methods for Detecting Carcinogens and Mutagens with the Salmonella/Mammalian-Microsome Mutagenicity Test. Mutation Research/Environmental Mutagenesis and Related Subjects, 31, 347-364. https://doi.org/10.1016/0165-1161(75)90046-1 
[16] Yoshida, E.H. (2014) Safety of Isolated Phytochemicals of Dipteryx alata Vogel under the Mutagenicity Parameter by the Ames Test. MPharm. Thesis, University of Sorocaba, São Paulo.

[17] Maron, D.M. and Ames, B.N. (1983) Revised Methods for the Salmonella Mutagenicity Test. Mutation Research/Environmental Mutagenesis and Related Subjects, 113, 173-215. https://doi.org/10.1016/0165-1161(83)90010-9

[18] Mortelmans, K. and Zeiger, E. (2000) The Ames Salmonella/Microsome Mutagenicity assay. Mutation Research/Fundamental and Molecular Mechanisms of Mutagenesis, 455, 29-60. https://doi.org/10.1016/S0027-5107(00)00064-6

[19] Vargas, V.M.F., Motta, V.E.P. and Henriques, J.A.P. (1993) Mutagenic Activity Detected by the Ames Test in River Water under the Influence of Petrochemical Industries. Mutation Research/Genetic Toxicology, 319, 31-45.

https://doi.org/10.1016/0165-1218(93)90028-C

[20] Hamel, A., Roy, M. and Proudlock, R. (2016) The Bacterial Reverse Mutation Test. In: Proudlock, R., Ed., Genetic Toxicology Testing, Academic Press, Cambridge, 79-138. https://doi.org/10.1016/B978-0-12-800764-8.00004-5

[21] Santos, F.V., Colus, I.M.S., Silva, M.A., Vilegas, W. and Varanda, E.A. (2006) Assessment of DNA Damage by Extracts and Fractions of Strychnos pseudoquina, a Brazilian Medicinal Plant with Antiulcerogenic Activity. Food and Chemical Toxicology, 44, 1585-1589. https://doi.org/10.1016/j.fct.2006.03.012

[22] Bernstein, L., Kaldor, J., McCann, J. and Pike, M.C. (1982) An Empirical Approach to the Statistical Analysis of Mutagenesis Data from the Salmonella Test. Mutation Research/Environmental Mutagenesis and Related Subjects, 97, 267-281. https://doi.org/10.1016/0165-1161(82)90026-7

[23] Arriaga-Alba, M., Montoya, R.M. and Aguirre, J.J.E. (2012) The Ames Test in Twenty-First Century. Journal of Toxicology, 2, 23-37.

[24] Stamberg, J., Werczberger, R. and Koltin, Y. (1979) Non-Mutagenicity of the Hair Dye, Henna, in the Ames Test. Mutation Research/Fundamental and Molecular Mechanisms of Mutagenesis, 62, 383-387. https://doi.org/10.1016/0027-5107(79)90093-9

[25] Freeman, H.S., Esancy, J.F., Esancy, M.K., Mills, K.P., Whaley, W.M. and Dabney, B.J. (1987) An Approach to the Design of Non-Mutagenic Azo Dyes: 1. The Identification of Non-Mutagenic Precursors and Potential Metabolites. Dyes and Pigments, 8, 417-430. https://doi.org/10.1016/0143-7208(87)85034-9

[26] Levy, D.D., Zeiger, E., Escobar, P.A., Hakura, A., Bas-Jan, M., Kato, M., Moore, M.M. and Sugiyama, K. (2019) Recommended Criteria for the Evaluation of Bacterial Mutagenicity Data (Ames Test). Mutation Research/Genetic Toxicology and Environmental Mutagenesis, 848, Article ID: 403074.

https://doi.org/10.1016/j.mrgentox.2019.07.004

[27] BfR (Federal Institute for Risk Assessment) (2020) Tattoo Inks: Risk Assessment for Pigment Blue 15:3 and Pigment Green 7. German Federal Institute for Risk Assessment, Berlin, 1-6.

[28] Murthy, R., Eccleston, D., Mckeown, D., Parikh, A. and Shotter, S. (2021) Improving Aseptic Injection Standards in Aesthetic Clinical Practice. Dermatologic Therapy, 34, Article ID: e14416. https://doi.org/10.1111/dth.14416

[29] Yoshida, E.H., Tribuiani, N., Sabadim, G., Moreno, D.A.N., Varanda, E.A. and Oshima-Franco, Y. (2016) Evaluation of Betulin Mutagenicity by Salmonella/Microsome Test. Advanced Pharmaceutical Bulletin, 6, 443-447. https://doi.org/10.15171/apb.2016.057 
[30] Isono, K. and Yourno, J. (1974) Chemical Carcinogens as Frameshift Mutagens: Salmonella DNA Sequence Sensitive to Mutagenesis by Polycyclic Carcinogens. Proceedings of the National Academy of Sciences of the United States of America, 71, 1612-1617. https://doi.org/10.1073/pnas.71.5.1612

[31] Barnes, W., Tuley, E. and Eisenstadt, E. (1982) Base-Sequence Analysis of HisC Revertants of the hiG46 Missense Mutation in Salmonella typhimurium. Environmental Mutagenesis, 4, 297 (abstr. Aa-1).

[32] Levin, D.E., Hollstein, M., Christman, M.F., Schwiers, E.A. and Ames, B.N. (1982) A New Salmonella Tester Strain (TA102) with AXT Base Pairs at the Site of Mutation Detects Oxidative Mutagens. Proceedings of the National Academy of Sciences of the United States of America, 79, 7445-7449.

https://doi.org/10.1073/pnas.79.23.7445

[33] Levin, D.E., Yamasaki, E. and Ames, B.N. (1982) A New Salmonella Tester Strain, TA97, for the Detection of Frameshift Mutagens: A Run of Cytosines as a Mutational Hot Spot. Mutation Research/Fundamental and Molecular Mechanisms of Mutagenesis, 94, 315-330. https://doi.org/10.1016/0027-5107(82)90294-9 